NBER WORKING PAPER SERIES

\title{
FOREIGN DIRECT INVESTMENT, EXCHANGE RATE VARIABILITY AND DEMAND UNCERTAINTY
}

Linda S. Goldberg

Charles D. Kolstad

Working Paper No. 4815

\section{NATIONAL BUREAU OF ECONOMIC RESEARCH 1050 Massachusetts Avenue \\ Cambridge, MA 02138 \\ August 1994}

Professor Linda S. Goldberg is grateful for the research support provided by the C.V. Starr Center at New York University and by NSF Grant HRD-9250102. Professor Charles Kolstad was supported in part by NSF Grant SES-9209943. George Childs provided excellent research assistance. Comments from Jose Campa, Linda Tesar and Frank Wolak have been appreciated. This paper is part of NBER's research program in International Finance and Macrocconomics. Any opinions expressed are those of the authors and not those of the National Bureau of Economic Research.

() 1994 by Linda S. Goldberg and Charles D. Kolstad. All rights reserved. Short sections of text, not to exceed two paragraphs, may be quoted without explicit permission provided that full credit, including (C) notice, is given to the source. 
NBER Working Paper \#4815

August 1994

\title{
FOREIGN DIRECT INVESTMENT, EXCHANGE RATE VARLABILITY AND DEMAND UNCERTAINTY
}

\begin{abstract}
Variable real exchange rates influence the country choice for location of production facilities by a multinational enterprise. With risk averse investors and fixed productive factors, a parent company should not be indifferent to the choice of production capacity location, even when the expected costs of production are identical across countries. If a non-negative correlation exists between real export demand shocks and real exchange rate shocks, the multinational will optimally locate some of its productive capacity abroad. The share of production capacity optimally located abroad increases as exchange rate volatility rises and as export demand shocks become more correlated. These theoretical results are confirmed by empirical analysis of quarterly United States bilateral foreign-direct-investment flows with Canada, Japan, and the United Kingdom.
\end{abstract}

Professor Linda S. Goldberg

Department of Economics

New York University

269 Mercer Street

New York, NY 10003

and NBER
Professor Charles D. Kolstad Department of Economics University of California Santa Barbara, CA 93106 


\section{INTRODUCTION}

The importance of exchange-rate variability for domestic and international investment flows has been argued in numerous contexts. In industrialized economies, the presumed effects of exchange-rate variability have influenced the choice of international monetary regimes. This issue arose in the early 1970s when the Smithsonian Agreement was discussed and again at the time of the Plaza Accord during the mid-1980s. In the early 1990s, the posited negative implications of variable exchange rates was one motivating theme in designing the Exchange Rate Mechanism (ERM) operable over currencies within the European Monetary System (EMS). The currency crises within the ERM in September 1992 and Spring 1993 refocused attention on the rationale for limiting short-term nominal exchange rate movements and on the validity of arguments that exchange rate variability is costly and dampens real economic activity. ${ }^{1}$

To date, much of the analysis on the real effects of variable exchange rates has considered whether variable exchange rates depress domestic exports and thereby worsen intemational competitiveness. Empirical tests over both developed and developing country export data have reached ambiguous conclusions. ${ }^{2}$ Other recent discussions of the additional costs of variable exchange rates center on the expense of: irreversible investment decisions, over-investment in productive capacity, and exchange-rate-induced incentives for domestic producers to located their manufacturing facilities outside of the United States. As in the literature on bysteresis in trade [Dixit (1989), Baldwin and Krugman (1989)], an important issue is whether transitory movements of exchange rates may lead to persistent restructuring if not deindustrialization of economies and whether this restructuring is stimulated or reduced when future exchange rates are uncertain. ${ }^{3}$

In this paper we emphasize and explore the implications of short-term exchange rate variability for foreign direct investment (FDl) flows. Short term movements of exchange rates about some trend corresponds to the concept of exchange rate volatility within exchange rate regime discussions. This

${ }^{1}$ Reductions in nominal exchange rate variability typically goes wgether with a reduction in real exchange rate volarility. See Mussa (1982) and Dombusch (1989). 'Edison and Melvin (1989) provide a critical survey of this literature.

${ }^{3}$ Goldberg (1993) and Campa and Goldberg (1994) finds that real exchange rate variability is correlaled with reduced invesment activity in U.S. manufacturing sectors. 
distinction deliberately excludes the longer term volatility measures that would include the persistent currency realignments peraining both to flexible and controlled exchange rate regimes. Our main theoretical result shows that if short-term exchange rate variability is to have a real impact on foreign direct investment, it will work in the direction of increasing the share of production activity that is located offshore. Our theoretical proposition is tested using United States bilateral FDI data for the 1978 to 1991 period. The empirical findings support the main theoretical results.

The intemational investment implications of variable exchange rates, often stated in policy discussions, have not been the subject of much formal analysis. The theoretical work on this subject is divided among production flexibility arguments and risk aversion arguments. The production flexibility argumerits have been expounded most recently by Aizenman (1992). ${ }^{4}$ Aizenman relies on a production structure whereby producers commit to domestic and foreign capacity ex anse and commit to employment decisions ex post, following the realization of some stochastic element such as nominal or real shocks. The theoretical results are an open-economy extension of the earlier literature on domestic investment, wherein the effects of price variability on invesment hinge on the sunk costs in capacity (i.e. the extent of investment irreversibilities), on the competitive structure of the industry, and overall on the convexity of the profit function in prices. ${ }^{5}$ In the production flexibility arguments, the important presumption is that producers can adjust their use of a variable factor following the realization of a stochastic input into profits. Without this variable factor, i.e. under a productive structure with fixed instead of variable factors, the potentially desirable effects on profits of price variability ${ }^{6}$ are diminished.

An altemative approach linking exchange-rate variability and investment relies on risk aversion arguments. One treatment of this argurnent emphasizes that higher exchange-rate variability lowers the

\footnotetext{
tIn the international context, de Meza and van des Ploeg (1987) also bave explored the "production-flexibility motive" behind the plant location decisions of a multinational enterprise, arguing that the structure of marginal-cost shocks and demand elasticities are key determinant of optimal investmenis in domestic and foreign capacity.

The linkage between invesumenl and price variability has been explored in a distinct domestically-oriented lilerature. See Hartman (1972), Abel (1983), Craine (1989), Pindyck (1988) and Cabalero (1991).

'This effect is based on the strength of the Jensen's inequality argumenl leadiog to profit convexity in variable prices.
} 
certainty equivalent expected exchange-rate level. 7 These certainty equivalent levels are used in the expected profit functions of firms that make investment decisions today in order to realize profits in luture periods. ${ }^{8}$ Altematively, one could maintain a distinction between the effects of exchange rate variability and the effects of exchange rate levels by directly modeling the utility of expected profits as decreasing in its variability. This enables one to examine the significance of multiplicative risk factors on expected profits, e.g. through both revenues and costs, and to isolate the effects of volatility in exchange rates versus the level effects. We follow this latter approach in this paper.

These production flexibility versus risk aversion approaches are both important but have merit under different circurnstances. When considering the existence and form of real effects of exchange rate variability, a clear distinction must be made between short term exchange rate volatility and longer term raisalignments of exchange rates. For sufficiendy short horizons, ex anse commitments to capacity and to related factor costs are a more realistic assumption than introducing a model based on ex post variable factors of production.' Hence, risk aversion arguments are more convincing than the production flexibility arguments posed in relation to the effects of short-term exchange rate variability. For variability assessed over longer dime horizons, the production flexibility motive provides a more compelling rationale for linking foreign direct investment flows to be variability of exchange rates.

In this paper we are concerned with the implications of exchange rate variability as measured from quarter to quaner or at even higher frequencies, for example over weekly or: monthly data. This is the type of variability implicit in less rigorous discussions of the real effects of exchange rate movements. Thus, our theoretical exposition relies heavily on arguments based on aversion to the volatility of profits: production flexibility arguments are less appropriate for this type of data frequency.

\footnotetext{
${ }^{7}$ See Cushman (1985, 1988).

BAnother recent theoretical argument about the linkage between exchange-rate movements and investment is based on the premise of imperfect capital markets [Froot and Stein (1991)]. In this setting, exchinge rate movements alter the relative wealth positions of competing international investors. By contrast, the emphasls of our paper is on the foreign direct investment effects of forecast exchange rate variability, instead of on contemporameous exchange rate levels.

'Anocher explanation is that the technology is such that capacity is fully utilized.
} 
In Section II, using a two-period model of the inter-temporal decision-making of a producer, we demonstrate how current assessments of future exchange-rate variability determine the portion of future market demand to be satisfied by production facilities based in domestic versus foreign economies. ${ }^{10}$ This decision is made in the context of multiplicative risk factors, entering both through revenues and production costs. Due to the emphasis of our model on short run activity, we do not permit ex post adjustment of a variable productive factor: producers cannot fire or hire workers the moment that they observe the realization of the stochastic exchange rate or of dernand. With labor contracts, most factors are quasi-fixed in the production function. In this environment, if the parent company is risk neutral and if exchange rate movements do not influence expected production costs, the parent company is indifferent to the location of its manufacturing facilities. By contrast, if the parent has even a small degree of risk aversion, the location of production facilities matters. The actual division of capacity across borders depends on the distributions of both exchange rate and demand shocks, and on the correlation between these shocks. If foreign production costs are positively correlated with revenues from those markets, a portion of productive capacity should be located abroad.

In Sections III and IV the theoretical propositions are examined empirically using quarterly bilateral foreign direct investment flows between the United States and the United Kingdom, Canada and Japan. The estimation interval spans from 1978 through 1991. The effects on FDI of real exchange rate variability, real demand shocks and the correlation between exchange rates and demand shocks are presented. Our main empirical finding is consistent with the theory: exchange rate volatility does tend to increase the share of productive capacity located abroad. Section $\mathrm{V}$ summarizes, cornpares our findings with those of previous studies, and concludes. ${ }^{21}$

\footnotetext{
${ }^{10} \mathrm{Sec}$ also Wolak and Kolstad (1991) who examine the covariance among differeat exchange rates in a partolio type analysis.

${ }^{11}$ Existing empirical sudies by Cushoman $(1985,1988)$ on pooled United States bilaterad FDI outfow data for the 19631978 period and inflow data for the period 1963-1986 concluded that exchange rate veriability was positively comelated with both sets of flows. Bailey and Tavlas (1991), using quarterly data on aggregate real direct investmeat inflows for 1976:1-1986:1, were unable wo find any adverse impect of either exchange rate vartability or misalignment.
} 
Finally, we would like to emphasize that it is not the objective of this paper to survey or test the merits of altemative explanations for FDI flows. Our paper asks only when and whether real exchange rate variability may influence the pattem of FDI activity. This emphasis is meant to supplement and not meant to eclipse or diminish the range of important motives for FDI exposited elsewhere. ${ }^{12}$ We focuses purely on the effects of expected volatility of exchange rates, without emphasizing the direct effects of exchange rates on relative production costs and relative cross-country wealth patterns. ${ }^{13}$

\section{THE MODEL}

Our basic model is a two-period one in which a domestic firm produces only for a foreign market, with a combination of domestic capacity (with output exported) and foreign capacity, sited with dernand. ${ }^{14}$ In the first period, the horizontally-integrated multinational decides on and commits to its capacity in its domestic and foreign plant locations. This investment in capacity represents the parent company's planned sales. The firm chooses productive capacity in both domestic and foreign locations either to maximize the present discounted stream of expected profits or the utility of those profits.

In period two, uncertainty in exchange rates and in demand are resolved: domestic and foreign facilities produce at capacity and take prices that clear the market. Investors repatriate their profits. Even though capacily is chosen in the first period, payments for investment capacity are made in the second period when revenues are realized.

Producers face an aggregate inverse demand function in the foreign country, denoted by $P(q)$. In our model $q$ represents the total production capacity of the multinational as well as (second-period)

${ }^{12}$ The "OLI viumvirate" [Ethier (1986)] is based on: i) ownership advantages, including patents or management advantages held by the source country; ii) locational advantages, wherein the source or destination country features motivare international investment, or iii) intemalization advantages wherein it is more advantageous for a firm to transact with its international subsidiary than to engage in arms length market activities.

${ }^{13}$ Relative wages are presented as incentives for FDI in the explanations based on "locational advantage". Froot and Stein (1992) argue that wealth effects of exchange rate changes may be the dominont channel for exchange rate level effects. Klein and Rosengren (1994) find support for the wealch channel on annual data for FDl flows into the Unjted States.

${ }^{14}$ The assumption that domestic firms produce only for foreign markets is for heuristic simplicity and not required for our resulis. The key requirement is for foreign demand movements to be more strongly correlated with the exchange rate than is domestic demand for domestic products. 
oulpul since it will never pay to under-utilize capacity. By making all factors of production fixed, we eliminate the ability of the producers to buy, via foreign direct investment, the option of channeling production ex post to the more profitable location. Domestic and foreign country variables are denoted by $d$ and $f$ respecively. Thus, $q_{d}$ and $q_{f}$ are domestic and foreign oulput Let $\theta=q_{f} / q$ define the fraction of capacity overseas. Clearly $0 \leq \theta \leq 1$.

Foreign demand is subject to random real shocks, denoted by $\delta$ with $E(\delta)=0$. In our model, this corresponds 10 vertical movement in the foreign demand curve. Denote the variance of $\delta$ by $\sigma_{8}^{2}$. The exchange rate, $e$, is defined in terms of domestic currency per unit of foreign exchange, also is subject to random shocks. Thus, large $e$ means a weak domestic curreocy. We choose units so that the expected value of the real exchange rate is unity, i.e. $E(e)=1$, and its variance is given by $\sigma_{\text {. }}^{2}$. Thus, we would expect (and assume) that $\sigma_{e}^{2}<1$ since $E(e)=1$ and $e \geq 0$. The correlation coefficient between $e$ and $\varepsilon$ is given by $\rho=\operatorname{Cov}(e, \delta) / \sigma, \sigma_{\mathrm{g}}$, where $\operatorname{Cov}(e, \delta)=E(e \delta)=\overline{e \delta}$. $1 \mathrm{~s}$

Althuugh a variely of tactors can explain $\rho$, the sign of the correlation between foreign demand and domestic real exchange rate shocks, consider the simple examples of foreign monetary and producivity shocks. An increase in the money supply in the foreign country would increase demand whilt raising foreign prices. With incomplete pass-through of the price changes into the bilateral exchinge rate. this leads to a short-term real appreciation of the foreign currency and a real depreciation of the domestic currency. Under this scenario, $\delta$ increases (i.e. it is positive) while $e$ also rises, implying a positive value for $p$. Atternatively, if the foreign monetary shock leads to short-term exchange rate overshooting, the domestic currency will appreciate in real terms and $\rho$ is negative. Foreign demand shocks also can be caused by foreign productivity shocks occurring outside of the sector in which our firm is operating. If the relative price index over foreign goods is reduced without a compensating nominal exchange rate adjustoment, the domestic currency appreciates in real terms and a positive $\rho$ value is observed. The absolute size of these correlations could increase with wage rigidities.

\footnotetext{
13If the distribution of $e$ is highly stewed, in would be possible for $\sigma_{a}^{2}>1$. We preclude this withour loss of generality.
} 
Without loss of generality, we assume that capacity costs are equal to 1 per unit of domestic output and equal to $e$ per unit of outpul abroad. Thus, $e$ is interpreted as the ratio of foreign to domestic production costs. Since ours is a short-lerm model, all production costs are embodied in the fixed factor, capacity. The profit function of the producer in period 2 is:

$$
\pi\left(q_{d}, q_{f}, e, \delta\right)=e \cdot(p(q)+\delta) \cdot q-q_{d}-e q_{f}
$$

Assessed in period 1 , the expected profits of the multinational, based on its capacity choice across domestic and foreign markets, are:

$E(\pi)=q \cdot(P(q)-1+\overline{e \delta}) \geq 0$

where individual rationality requires expected profits to be nonnegative. Our Eurst basic result follows directly from (2):

Proposition 1: When exchange rase and foreign demand shocks are positively (negatively) correlased, expecsed product price is less (more) than expected marginal cost.

One interesting implication of this result is that expected product price may be less than expected costs under profit-maximizing behavior and without dumping motives. Thus, the dominance of positively correlated exchange rates and foreign demand shocks could lead to pricing behavior that is incorrecty interpreted as related to dumping. To relate these types of shocks to investment activities, we consider two versions of the model: one where the producer is risk-neutral and one where the producer is risk averse.

\section{II.1Risk Neutrality}

In the case of risk neutrality, the effect of altered aggregate production levels on total expected profits is given by:

$$
\frac{\partial E(\pi)}{\partial q}=P(q)+P^{\prime}(q) \cdot q-1+\overline{e \delta}
$$

and the first-order conditions for profit maximization are given by:

$$
P(q)+P^{\prime}(q) \cdot q=1-\overline{e \delta}
$$


The left-hand side of (4) represents expected marginal revenues whereas the right-hand side terms represent (constant) marginal costs adjusted for the covariance between exchange-rate shocks and foreign dernand shocks for the multinational product. Our second result follows from (4):

Proposition 2: If the domestic firm is risk neutral and expected production costs are the same in domestic and foreign markets, then:

a) If $\rho>0 \quad(\rho<0)$, marginal costs exceed (are less than) expected marginal revenues and total output of the multinational expands (shrinks) relative to the deterministic case.

b) The firm is indifferent regarding the location of production facilities.

In this simple two-period model with risk neutrality, the multinational's investment in capacity today is a function of the correlation between the exchange rate used to value export eamings and the foreign dernand for the multinational's product. Under risk neutrality, the total volume of production may be sensitive to the size and correlations between shocks, but the location of production facilities is not sensitive. The important point to keep in mind is that the stochastic nature of exchange rates and demand matter only to the extent that these shocks are correlated. Without risk aversion, and without expected relative wage or marginal cost effects across countries, foreign direct investment flows will not be significantly influenced by altered variability of exchange rates.

The correlation between export demand shocks and real exchange rate shocks is important in Proposition 2 and, in general, will be shown to be an important theoretical determinant of the location of investrnent facilities.

\section{I1.2 Risk Averse Producer-Investocs}

Suppose that producers are risk-averse. ${ }^{16}$ Assume that the expected utility of profits can be writen as a function of expected profits and the variance of profits.

\footnotetext{
${ }^{16}$ Dufey and Srinivasula (1984) review the weaknesses of common arguments against the claim that firms are risk averse and that firms should bedge against foreign exchange risk. First, risk aversion arises if corparate management seeks to avoid default risk and the costs of financial distress, where these costs rise with the variability of the net casb lows of the firm. Moreover, managers (and shareholders) may be persconally heavily exposed to the risk of variable firm profits and thereby would altempt to eliminate this rist Rodriguez (1981) provides supporting evidence on management attitudes and behavior. Another common argumeat against firm risk aversion is based on the Modiglianj-Miller theorem. This theorem implies that whatever the firm can do (in terms of bedge activities), tovestors can do: if exchange
} 


$$
E(u(\pi))=U(E(\pi), \operatorname{Var}(\pi))
$$

This expected utility specification is justified if utility is quadratic or if the uncertainty induced in protits is normally distributed [Jarrow, 1988]. We will assume $(e, \delta)$ are bivariate normal. ${ }^{17}$ We also assume that $E(u(\pi))$ is strictly concave, a somewhat stronger assumption. Using the properties of stochastic exchange rates and dernand, the variance of profits is given by: ${ }^{18}$.

$$
\operatorname{Var}(\pi)=q^{2}\left(\sigma_{c}^{2}(P(q)-\theta)^{2}+2(P(q)-\theta) \rho \sigma_{c} \sigma_{\delta}+\rho^{2} \sigma_{c}^{2} \sigma_{6}^{2}+\left(1+\sigma_{c}^{2}\right) \sigma_{b}^{2}\right)
$$

where $\theta=q_{f} / q$. Using equations (5), (2) and (6), one can determine the period one investments in domestic and foreign capacity (actually $q$ and $\theta$ ) that will maximize investor utility. The goal, maximizing (5) subject to $q \geq 0,0 \leq \theta \leq 1$, and (2), represents a constrained optimization problem. Consider the case where (2) is non-binding. The first-order conditions depend on whether optinal $q$ and $/$ or $\theta$ are at the boundaries.

Assume $\gamma=-2 U_{2} / U_{1}>0$ is constant where $U$ is defined in (5) and the $U_{i}$ denote the respective first derivarives. Then, note that

$$
\begin{array}{ll} 
& \frac{\partial E(u(\pi))}{\partial q}=U_{1} \frac{\partial E(\pi)}{\partial q}+U_{2} \frac{\partial \operatorname{Var}(\pi)}{\partial q}=U_{1}(A-P(q) B) \\
& \frac{\partial E(u(\pi))}{\partial \theta}=U_{1} \frac{\partial E(\pi)}{\partial \theta}+U_{2} \frac{\partial \operatorname{Var}(\pi)}{\partial \theta}=U_{1} B \\
\text { where } \quad A=P(q)+P^{\prime}(q)_{q}-1+\overline{e \delta}-\frac{\gamma}{q} \operatorname{Var}(\pi) \\
B=\gamma q^{2}\left((P(q)-\theta) \sigma_{c}^{2}+\overline{e \delta}\right)
\end{array}
$$

From the assumed strict concavity of $E(u(\pi))$, a constrained maximum of (5) exists, although of course it may be trivial $(\dot{q}=0)$. This assumes regularity (strict complementarity) holds. Note that the

risk is to be hedged, it need not be done by the firm. But, this argument is weakened by impodiments to more efficient hedging by individuals, including firm-level access to lower cost hedges and asymmetries across managers and shareholders in information about firm-level exposure.

${ }^{17}$ Note that we stated earlier that $\mathrm{E}(e)=1$ and $\mathrm{e}$ is non-Degative. The exchange rate process is assumed centered about one rather than zero. Because of normality, $E(e \delta)=\rho \sigma_{,} \sigma_{\delta}, E\left(e^{2} \delta\right)=2 \rho \sigma_{e} \sigma_{\delta}$, and $E\left(e^{2} \delta^{2}\right)=2 \rho^{2} \sigma_{e}^{2} \sigma_{\delta}^{2}+\left(1+\sigma_{e}^{2}\right) \sigma_{\delta}^{2}$.

${ }^{18}$ Equation (6) is derived by taking the expected value of the squared difference between profits as defined in equation (1) and expected profits as presented in equation (2). 
lisst-order conditions at various boundaries differ primarily in the $A$ term in equation (7a). Therefore, the following resuls hold:

Lemma 1: Assuming regularity conditions hold and expected profits are positive, for any optimal g>0. the following applies:

$$
P(q)-\theta+\rho \frac{\sigma_{\delta}}{\sigma_{.}}\left\{\begin{array}{l}
=0 \Leftrightarrow q_{d}, q_{1}>0 \\
<0 \Leftrightarrow q_{1}=0 \\
>0 \Leftrightarrow q_{d}=0
\end{array}\right.
$$

The basic interpretation of this result is that, with even a small degree of risk aversion. the parent company is not indifferent to the location of facilities, even when the expected unit costs of production are equal across facilities. Foreign direct investnent flows will be influenced by the expecued variability of real exchange rates.

It is important to remember that $\rho, \sigma_{,}$and $\sigma_{3}$ are exogenous to the firm. Based on these characteristics of the distributions of the e's and $\delta$ 's, the firm chooses $q_{f}$ and $q_{f}$ (both of which may be zero). Lemma I leads direculy to the following corollary:

$$
\begin{aligned}
& \text { Corollary 1: Under the conditions of Lemma I with } g>0 \text {, the following must hold: } \\
& \left.\qquad \begin{array}{l}
q_{1}=0 \Rightarrow 1<D \\
q_{d}>0 \Rightarrow 0 \leq D
\end{array}\right\}:\left\{\begin{array}{l}
D \leq 1 \Rightarrow q,>0 \\
D<0 \Rightarrow q_{d}=0
\end{array}\right. \\
& \text { where } D=-\rho \frac{\sigma_{s}}{\sigma_{d}}\left(1-\sigma_{d}^{2}\right)
\end{aligned}
$$

Proof: Use equation (8) and equation (2) to derive equation (9).

There are a number of implications of Corollary 1. First, with $e$ and $\delta$ positively correlated, foreign demand is high precisely when the domestic currency is weak By locating production facilities overseas, the producer minimizes the variance of expected profits and increases expected utility. Thus, the expected utility of profits is maximized by locating all production in the foreign country. Second. when there is only exchange rate uncerainty and no demand uncerainty (or when these shocks are orthogonal), then it is always desirable to locate some production overseas, i.e. $q_{f}>0$. This may be 
the case if exchange rates are determined purely by short-term speculation in financial markets and are unrelated to other market fundamentals. Under risk aversion, there always will be production located abroad, in contrast to the risk neutrality case where the location choice is indeterminate. Third, if demand and exchange rate shocks are modestly negatively correlated it will be desirable to have some domestic production and not place all of one's capacity offshore.

Corollary $l$ also states that when specific patterns in domestic and foreign investment activity are observed, there are relationships between exchange rate and foreign demand shocks that must be satisfied. For example, if no capacity is located offshore, exchange rates and foreign demand shocks musi be negatively correlated. If there is at least some capacity sourced at home, then these shocks must be positively correlated.

\section{3 Comparative Statics:}

Having defined the condition for optimal choice of $q_{d}$ and $q_{f}$, we now turn to the question of how these optimal choices are affected by the scale of the uncertainty in exchange rates and demand and by the covariance structure between these shocks.

Proposition 3: Assume at an optimal $q_{1}$ that $q_{d}, q_{f}>0$. Then:

$$
\frac{\partial \theta^{*}}{\partial \sigma_{e}}>0 \quad \frac{\partial q^{*}}{\partial \sigma_{e}}<0
$$

Broof: See Technical Appendix.

This result states that the greater the variability of exchange rates, the larger the share of capacity located offshore, although overall capacity declines. We cannot conclude whether or not the absolute level of FDI rises or falls. Implicit in this proposition is the fact that exchange rate and demand shocks are negatively correlated (from Corollary 1); otherwise $q_{d}=0$. This is somewhat as expected since only profits as opposed to the entire price are exposed to exchange rate fluctuations with foreign investment Further comparative statics results emerge with some restrictions on the form of the demand function: 
Proposition 4: Assume at an optimal $q$. that $q_{d}, q_{f}>0$. Further assume that demand is nor excessively convex, i.e. $P(q)+P "(q) q<0$ for all $q>0$. Then:

$$
\frac{\partial \theta^{*}}{\partial \rho}>0
$$

Rroof: See Technical Appendix.

By assumption $\rho<0$ from Corollary 1. A negative $\rho$ means that foreign demand is high ( $\varepsilon$ is large) precisely when the domestic currency is strong. But, as this relationship erodes by $\rho$ becoming larger, we move closer to the region of $\rho>0$ where all production is foreign. Thus, as $\rho$ rises, $\theta$ rises. When $0<\theta<1$, an increase in exchange rate variability which would otherwise tend to increase the share of foreign investment can be offset by an increase in the absolute value of the covariance berween demand shocks and exchange rate shocks.

\section{II.4 Testable Implications}

Our model of the implications of real exchange rate variability yields clear predictions for bilateral flows of foreign direct investment under fixed productive factors. Under risk neutrality, FDI share is not expected to be correlated with variability measures. By contrast, with just a small degree of risk aversion and if $\rho \geq 0$ : positive FDI always occurs (Corollary 1). This share of total capacity located abroad would be unresponsive to exchange rate variability in this regime only if all capacity already is located on foreign soil. With the share of FDI in total investment bounded away from zero and one and $\rho \leq 0$, the FDI share increases as exchange rate variability rises (Proposition 2). Furthermore, as long as demand is not excessively convex, the FDI share increases as the correlation between exchange rate and real demand shocks rises (Proposition 3).

Defining a source country by the index $i$ and a destination market by the index $j$, these theoretical propositions give rise to the following testing equation:

$\theta_{\imath}^{j}=\beta_{0}^{i}+\beta_{1}^{i} \sigma_{a}^{j}+\beta_{2}^{i} \sigma_{b s}^{j}+\beta_{3}^{i} \rho_{1}^{j}+\beta_{4}^{i} e_{t}^{j}+\beta_{3}^{j} y_{1}^{j}+\mu_{1}^{i}$

where the share of production capacity from the source country $i$ located in the destination country $j$ is a function of: (i) the volatility of the bilateral real exchange rate, $\sigma_{\lrcorner,}^{j}$, which is expected to enter with 
a positive coefficient $\beta_{1}: 19$ (ii) the volaulity of real destination market demand, $\sigma_{s,}^{j}$, for which the coefficient $\beta_{2}$ is ambiguously signed; (iii) the correlation between the real exchange rate and real destination market demand, $p_{r}^{i}$, which is expected to enter with a positive coefficient $\beta_{3}$; and (iv) the real exchange rate $e_{r}^{\ddot{p}}$, which is expected to enter with a negative coefficient $\beta_{4}$. Destination market demand, $g d p_{\imath}^{i}$, also is included as an explanatory variable in this equation although the sign and significance is not determined in our model. ${ }^{20}$

\section{The DATA}

These theoretical predictions are tested using bilateral foreign direct investment activity between the United States and the United Kingdom, Japan and Canada. The country choices for bilateral partners is partially motivated by data availability and partially motivated by the importance of these countries to the United States in foreign-direct-investment flows.

Our model treats foreign-direct-investment as total investment or capacity location choice by the parent in a subsidiary at any point in time. We use flow data on bilateral investments, with the foreign direct investmenl data drawn from United States balance-of-payments tables. For inflows into the United States, these data capture the increase in the book value of equity in United States businesses or asset deemed under foreign control held by foreign persons. An analogous definition applies to ouffows originating in the United States and invested abroad. ${ }^{21}$ Our sample period begins in 1978 in order to minimize estimation problems stemming from the major step-up in the early 1970 s of interest in the United States as a target for foreign investment [Caves (1989)]. The data are quarterly, from 1978:I through 1991:IV and are fully documented in the appendix. To summarize, FDI $\left(q^{j}\right)$ is from the Survey of Current Business; total levels of investment $\left(q_{i}\right)$ are from country specific sources;

\footnotetext{
${ }^{19}$ Assuming some risk aversion.

20We do nol control for changes in tax laws, which bave not been foind to be sigmificant determinants of real bibateral FDI flows of the United States. See Slemrod (1989) on US inward bilateral FDI flows. Klein and Rosengren (1994) had consistenl fiadings: tax changes did not alter the partern of exchange rate level effects on bilateral investments. We also do not examine the importance of avoiding trade restrictions through FDI, or of eatry barriers to inflows of FDI, as in the analysis of inward Japanese flows by Laprence (1993).

${ }^{15}$ These balance-of-payments data are subject to a well-known shortooming: reinvested earnings of foreign subsidiaries, as invested wealth by the parent, are not appropriately measured. This cmission is more of a problem in the late 1970s than in the 1980s, when reinvested earaings were a much smaller portion of bilateral equity positions [Lipsey (1992)].
} 
bilateral exchange rates and GDP are from the International Financial Statistics (IMF), and the consumer price indices are $\mathrm{CPI}$ data drawn from the $O E C D$.

Construction of FDI Shares: The shares $\theta$ are constructed by dividing the FDI outflows from a source country to a destination market by a measure of investment activity in the source country. The two-way bilateral flows are between the United States and Canada, Japan, and the United Kingdom. While this measure captures the flavor of our model, there are limitations in this data. The theory considers movements in FDl relative to domestic investment. However, for these purposes the appropriate measure of domessic investment is not aggregate source country investment but instead is investment in the total new capacity of export-oriented production firms. Unfortunately this measure is unavailable. The second shorcoming of our data is that the foreign direct investment data miss important forms of reinvestment of earnings and tend to understate total foreign investment.

Volatility and correlation measures: For each of the bilateral real exchange rates $e^{\prime \prime}$ used, both the levels and distributions of each real exchange rate are constructed from the vantage point of the respective source countries. Exchange rate volatility is constructed as the standard deviation of the exchange rate over rolling samples of twelve quarters of data, prior to and inclusive of each period th normalized by the mean level of the exchange rate within the interval 22 This measure $\sigma^{j}$ incorporates both the "predictable" and "unpredictable" components of exchange rate movernents. It is particularly informative when exchange rates are close to randorn walks. An analogous procedures also is used to construct a proxy for real demand variability for each destination country, $\sigma_{b}^{\prime}$ and for the correlation between. the real exchange rates and real GDP series, $\rho^{\prime}$.

The USS/Can\$ real exchange rates exhibited the smallest amount of variability, at roughly one third the size of the dollar/yen and dollar/pound levels. The variability of the dollar/yen exchange rates increased significanuly in the 1985 to 1990 period as compared with levels in 1978 to 1984. Negative $\rho^{i}$ (correlations between exchange rates and foreign real GDP) generally are observed from the Japanese perspective for its assessment of the United States as a destination country for investments

\footnotetext{
22We normalize because the theoretical model assumes no stift over time in the expecied exchange rate.
} 
and for Japanese products. ${ }^{23}$ Such negative correlations also are observed from the perspectives of the United Kingdom and Canada in assessing flows to the United States in the second half of the 1980s. The United States flows to Canada were primarily under a regime of negative correlations in the late 1970s and early 1980s. This could suggest that monetary shocks in the United States markets or possibly fiscal shocks in foreign markets were dominant during this period.

Stationarity Properties of the Data: We have conducted augmented Dickey-Fuller (ADF) lests over the data used in the empirical work. Non-stationarity is rejected for all ratios constructed for FDI activity with the exception of the shares of United States investment into Japan and into the United Kingdom. For real FDI series (the nominal series deflated by the home price index), the only series for which we cannot reject the existence of a unit root is real FDI of Japan into the United States. ${ }^{24}$

With the possible exception of the exchange rate and GDP series, we do not have unit root problems for the right hand side (RHS) variables included in regressions for bilateral outhows from the United States or inflows into the United States from Canada. However, inflows into the United States from Japan and from the United Kingdom may be nonstationary series.2s Regression inference is, of course, complicated by the observation that stationary series should not be regressed against nonstationary series. However, our conclusions regarding which series are nonstationary are biased in favor of not rejecting unit roots. Thus, we account for the possibility the ADF tests yield incorrect results by following regression procedures suggested by Stock (1992): those right hand side variables that may have unit roots are entered both in level and first difference format into the regressions. Dependent variables that may have unit roots altematively enter in level and first difference format

\footnotetext{
${ }^{23}$ This is interesting when considered in the context of Proposition 1. Recall that one interpretation of Proposition 1 is that the existence of positive correlations between exchange mies and fortign demand shocks may inappropriately lead to dumping charges. Since the Japanese observe negative correlations, our model does not suggest thal evidence provided in support of dumping charges would be misconstrued.

${ }^{24}$ See the appendix for results of these tests.

${ }^{25}$ The ADF test is being applied to small samples, generally 52 observations, and, as shown by Stock (1992) is biased against rejection of unit roxots in the dara.
} 


\section{RESULTS OE EMIPIRICALANALYSIS}

The implications of exchange rate and demand patterns for the share of investment activity located overseas are reported in Table 1. For each of the bilateral investment shares we also tested whether the FDI shares responded differentially to the volatility measures across regions of positive and negative correlations between demand shocks and real exchange rate shocks. If there was a differential response across positive versus negative correlations, the regression results are reported. ${ }^{26}$

Exchange rate variability had a positive and statistically significant effect on four of the six bilateral FDI shares: real exchange rate variability increased the share of total United States investment capacity located in Canada and in Japan, and increased the share of Canadian and United Kingdom investment located in the United States. These results are consistent with the predictions of Proposition 3. However, in contrast to the conditions highlighted in the theoretical propositions, we did not find evidence that the effects of real exchange rate volatility on investment significantly differed across periods when there were positive and negative correlations between exchange rate and demand shocks. Of the remaining two sets of regressions where real exchange rate variability was not statistically significant, the regressions on shares of FDI relative to total source country investment were subject to some econometric problems. Japanese FDI shares into the United States is potentially a nonstationary series and first differences of this dependent variable were used in the regressions. The regression for United States FDI share into the United Kingdom was subject to problems of heteroskedasticity and corrected using a Newey-West procedure. Thus, exchange rate variability enters with the expected sign and was statistically significant except when problems arose in estimating the regression equations.

\footnotetext{
${ }^{26}$ We also estimated regressions using real FDI levels rather than FDI shares. We do not report these regression results because they are not directly related to the theoretical propositions provided in Section II. Howeve, where relevant and informative we note these results in the texL In all of the OLS regressions performed, the regressions contain seasonal dummy variables and serial correlation adjustments. The coefficients on antoregressive and seasonal terms are not reported in the summary tables but are available upon request Where appropriate, beteroskedasticity and serial correlation problems are corrected using Newey-West procedures. The models were chosen based upon the BreaschGodfrey test for serial correlation, various versions of White's test for beteroskedasticity, and an ARCH test of four lags. If the models passed all of these tests, their inference is accepted. If not, the models were estimated by a GMM procedure with a Newey-West correction for serial correlation. If required, the regression equation is modified 10 account for nonstationarities by also entering the potentially first order integraled series into the regressions in first differences.
} 
Table 1: FDI Outflows as a Share of Source Country Investment $\theta_{1}^{i j}=\beta_{0}^{i}+\beta_{1}^{i} \sigma_{s s-1}^{i}+\beta_{2}^{i} \sigma_{s t-1}^{j}+\beta_{3}^{i} \rho_{t-1}^{i}+\beta_{4}^{i} e_{t-1}^{i j}+\beta_{3}^{i} y_{t-1}^{j}+\mu_{t}^{i}$

\begin{tabular}{|c|c|c|c|c|c|c|c|c|}
\hline \multirow{2}{*}{$\begin{array}{c}\text { RHS variables } \\
\\
\sigma_{e}\end{array}$} & \multicolumn{8}{|c|}{ Direction of Bilateral FDI as Share of Source Country Investment } \\
\hline & \multirow{2}{*}{ 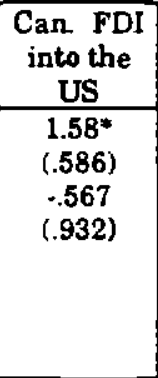 } & \multirow{2}{*}{$\begin{array}{c}\begin{array}{c}\text { U.S. FDI } \\
\text { into } \\
\text { Canada }\end{array} \\
.225 \\
(.114) \\
\ldots \\
- \\
- \\
-\end{array}$} & \multicolumn{2}{|c|}{$\begin{array}{c}\text { UK FDI } \\
\text { into the } \\
\text { United States /a }\end{array}$} & \multirow{2}{*}{$\begin{array}{c}\begin{array}{c}\text { US FDI } \\
\text { into the } \\
\text { UK }{ }^{+}\end{array} \\
. .354 \\
(.378)\end{array}$} & \multicolumn{2}{|c|}{$\begin{array}{c}\text { Japan FDI } \\
\text { into the } \\
\text { United States } / \mathrm{a}\end{array}$} & \multirow{2}{*}{$\begin{array}{c}\begin{array}{c}\text { US FDI } \\
\text { into } \\
\text { Japan }\end{array} \\
.037 * * \\
(.021) \\
-.021 \\
(.020)\end{array}$} \\
\hline $\begin{array}{c}\sigma e \\
D^{*} \sigma e \\
\Delta \sigma e \\
D^{*} \Delta \sigma e\end{array}$ & & & $\begin{array}{l}.525^{*} \\
(.440) \\
0.637 \\
(1.24)\end{array}$ & $\begin{array}{c}. .492 \\
(.962) \\
-.198 \\
(.497) \\
\end{array}$ & & $\begin{array}{c}-.027 \\
(.022) \\
-.114^{*} \\
(.040)\end{array}$ & $\begin{array}{c}.012 \\
(.039)\end{array}$ & \\
\hline $\begin{array}{r}\sigma_{\delta} \\
\Delta \sigma_{\delta}\end{array}$ & $\begin{array}{c}.851 \\
(1.07)\end{array}$ & $\begin{array}{c}.394 \\
\text { (.396) }\end{array}$ & \begin{tabular}{|c|}
-0.454 \\
$(.860)$ \\
-1.140 \\
$(2.61)$ \\
\end{tabular} & $\begin{array}{c}-.937 \\
(3.82) \\
\end{array}$ & $\begin{array}{l}.819 \\
(.766) \\
-.687 \\
(.516) \\
\end{array}$ & $\begin{array}{c}-.270^{4} \\
(.050) \\
.027 \\
(.197) \\
\end{array}$ & $\begin{array}{c}.161 \\
(.334)\end{array}$ & $\begin{array}{c}.091 \\
(.097) \\
.131 \\
(.273) \\
\end{array}$ \\
\hline $\begin{array}{c}\rho \\
D^{*} \rho \\
\Delta . \rho \\
D^{*} \Delta . \rho\end{array}$ & $\begin{array}{l}.072^{*} \\
(.030) \\
-.128 * * \\
(.065)\end{array}$ & $\begin{array}{c}.008 \\
(.010)\end{array}$ & $\begin{array}{l}-0.005 \\
(.020) \\
\\
-0.055 \\
(.044)\end{array}$ & $\begin{array}{c}-.012 \\
(.021) \\
.033 \\
(.046) \\
-.229^{*} \\
(.090) \\
.401^{*} \\
(.138)\end{array}$ & $\begin{array}{c}.012 \\
(.020)\end{array}$ & $\begin{array}{r}.003 \\
(.009)\end{array}$ & $\begin{array}{l}-8 \mathrm{E}-4 \\
(.005)\end{array}$ & $\begin{array}{l}.001 \\
(.005) \\
.013^{* *} \\
(.008)\end{array}$ \\
\hline $\begin{array}{l}e \\
\Delta e\end{array}$ & $\begin{array}{l}. .077 \\
(.239) \\
.551 * * \\
(.298) \\
\end{array}$ & $\begin{array}{c}-2 \mathrm{E}-4 \\
(.070) \\
-.128 \\
(.117) \\
\end{array}$ & $\begin{array}{c}-0.094 \\
(.113) \\
0.413 \\
(.286) \\
\end{array}$ & $\begin{array}{c}-.082 \\
(.241) \\
\end{array}$ & $\begin{array}{c}.023 \\
(.024) \\
.009 \\
(.020) \\
\end{array}$ & $\begin{array}{l}-6 \mathrm{E}-6 \\
(8 \mathrm{E}-5) \\
7.6 \mathrm{E}-5 \\
(8.6 \mathrm{E}-5) \\
\end{array}$ & $\begin{array}{c}6 \mathrm{E}-6 \\
(9 \mathrm{E}-5)\end{array}$ & $\begin{array}{l}-2.99^{*} \\
(1.44) \\
3.00^{* *} \\
(1.73) \\
\end{array}$ \\
\hline $\begin{array}{l}j \\
\Delta y j\end{array}$ & $\begin{array}{c}3 E-4 \\
(9 E-3) \\
5 E-4 \\
(4 E-3) \\
\end{array}$ & $\begin{array}{l}-2 E-4 \\
(4 E-4) \\
2 E-3 \\
(9 E-4)\end{array}$ & $\begin{array}{l}0.001^{*} \\
(.000) \\
1.8 \mathrm{E}-3 \\
(.002) \\
\end{array}$ & $\begin{array}{l}1.5 \mathrm{E}-3 \\
(1.25-3)\end{array}$ & $\begin{array}{l}-.002 \\
(.001) \\
.001 \\
(.001) \\
\end{array}$ & $\begin{array}{c}8 E-5^{*} \\
(268-5) \\
62-5 \\
(1 E-4)\end{array}$ & $\begin{array}{c}5 E-5 \\
(16 E-5)\end{array}$ & $\begin{array}{c}2 E-7^{*} \\
(7 E-8) \\
9 E-8 \\
(8 E-7) \\
\end{array}$ \\
\hline $\begin{array}{c}\text { Adj. } \mathrm{R}^{2} \\
\text { D.W. } \\
\text { F-statistic } \\
\text { tobeervation }\end{array}$ & $\begin{array}{c}.176 \\
2.17 \\
1.64 \\
43 \\
\end{array}$ & $\begin{array}{l}.068 \\
2.04 \\
1.26 \\
47 \\
\end{array}$ & $\begin{array}{c}.267 \\
2.09 \\
2.03 \\
46 \\
\end{array}$ & $\begin{array}{l}.322 \\
2.29 \\
2.24 \\
49 \\
\end{array}$ & $\begin{array}{c}-.062 \\
1.94 \\
48 \\
\end{array}$ & $\begin{array}{c}.696 \\
1.99 \\
6.25 \\
46 \\
\end{array}$ & $\begin{array}{c}.272 \\
2.14 \\
2.64 \\
45\end{array}$ & $\begin{array}{l}.337 \\
2.04 \\
2.40 \\
45 \\
\end{array}$ \\
\hline & & & & & & & & \\
\hline
\end{tabular}


Proposition 4 stated that, under particular restrictions about the structure of demand, an increase in the covariance between destination market demand shocks and real exchange rate shocks would lead to an increase in the FDl share. This direction of response is supported for all data on levels of outflows of FDI from the United States and for Canadian FDI into the United States. However, the results were statistically distinct from zero only for two of the six bilateral flow shares. The lack of statistical significance on four of these six terms may be due to the relatively short testing period of our regressions. Altematively, the series may violate the convexity restrictions on the demand functions stated in Proposition 4, or there may be nonlinearities or discrete regimes which we do not examine in the relationship between correlation movements and FDI shares.

Although theory did not yield clear predictions about the effects of variability of destination market demand, this force was statistically significant only for Japanese investunent into the United States: the higher was United States real GDP volatility, the smaller was the share of Japanese investment sited in the United States.

Exchange rate levels (and first differences) have been found to be highly significant in previous empirical studies of real FDI activity tested over annual data. By most theoretical arguments, a domestic currency depreciation is expected to decrease source country foreign direct investments abroad. The basic arguments fall into two camps: either real depreciations raise the relative price of foreign productive resources or increase the relative competitiveness of foreign competitors bidding for the same production site. Note, however, that these arguments apply to levels of FDI and additional assumptions are required before they pertain to the share data on FDI as used in our regressions.

In our tests using quarterly data, the exchange rate levels entered with the expected sign in all regressions: exchange rate depreciations of the source country currency lead to a reduction in investment flow shares to foreign markets. However, these effects generally were neither large or statistically significant In part the weak role of exchange rate levels may be attributable to the potential nonstationarity of quarterly exchange rate series. It also may be atrributable to a valuation effect: although the absolute level of FDI may decline in response to a domestic currency depreciation, 
the domestic currency value of that FDI at least partially increases due to the change in the exchange rate. Our lindings are consistent with Lipsey's (1992) interpretation of the potential effects of exchange rate changes on investment: a depreciation of the domestic currency does make foreign facilities more expensive, and probably leads to a reduction in demand for physical investment abroad. However the overall impact on the value of foreign direct investment reguires a high elasticity of demand for investment assets. Our results suggest that either the quarterly movements in exchange rate levels do not matur for FDI flows, or the elasticities of investment demand are not large enough so that domestic currency depreciations actually reduce investment flows abroad.

\section{CONCLUSIONS}

This paper has contributed to our understanding of the real effects of variable exchange rates in several dimensions. First, we have argued that there are two classes of models that link real exchange rate variability to international investment activity. The first class of model relies on the argument that

producers engage in international investment diversification in order to achieve ex post production flexibility and higher profits in response to shocks. This argument is relevant to the extent that ex post production flexibility is possible within the window of time before the realization of the shocks. This suggests that the production flexibility argument is less likely to pertain to short term volatility in exchange rates than to realignments over longer intervals.

Since many of the discussions of the merits of fixed versus flexible exchange rate regimes emphasize the implications of shon term volatility, the group of arguments based on the risk-taking characteristics of producers are more likely to be relevant for investment activity in domestic and foreign markets. We use a simple model to illustrate the linkage between exchange rate variability and the decision by multinational producers to locate production facilities on domestic versus foreign shores. Exchange rate variability is expected to have real effects on the share of domestic investront resources channeled abroad in a limited set of circumstances. If investors are risk neutral, the model does not predict any statistical relationship between exchange rate volatility and the allocation of 
production facilities between domestic and foreign markets. But, if there is risk aversion among producers, exchange rate volatility may expand the share of investment resources located offshore.

Our analysis of two-way bilateral foreign direct investment flows between the United States, and Canada, Japan, and the United Kingdom yielded empirical results consistent with the theory: exchange rate volatility tended to stimulate the share of investment activity located on foreign soil. Exchange rate volatility did not have statistically different effects on investment shares when one distinguishes between periods where real or monetary shocks dominate exchange rate activity. Real depreciations of the source country currency were associated with reduced investment shares to foreign markets, but these results generally were statistically insignificant in our quarterly data.

Although the theoretical work concluded that the share of total investment located abroad may rise as exchange rate volatility increases, this does not imply that exchange rate volatility depresses domestic invesunent activity. In order to conclude that domestic aggregate investment declines, one must show that the increase in domestic outflows is not offset by a rise in foreign inflows. In the aggregate United States economy, exchange rate volatility has not had a large contractionary effect on overall investment [see Goldberg (1993) and Campa and Goldberg (1994)].

These results lead to the conclusion that exchange rate volatility can contribute to the intemationalization of production activity without depressing economic activity in the home market. Thus, it is incorrect to assume that the selection of a flexible exchange rate system will lead to depressed economic activity. If the lessons drawn from United States investment flows can be viewed in a broader context, the choice of a controlled exchange rate regime is not clearly associated with a climate more conducive to economic growth. Even if other studies conclude that exchange rate volacility depresses expon activity, our conclusions are not contradicted: exchange rate volarility can spur an increase in intemational capital flows that can substitute for intemational trade in goods without depressing overall economic activity. 


\section{REFERENCES}

Abel, A. (1983) "Optimal Investment Under Uncertainty," American Economic Review vol. 73 no.l pp.228-33.

Aizenman, J. (1992) "Exchange Rate Flexibility, Volatility and Pattems of Domestic and Foreign Direct Investment," IMF Staff Papers.

Bailey, M. and G. Tavlas (1991), "Exchange Rate Variability and Direct Inves(ment," The Annals AAPSS, vol.516 (July) pp.106-116.

Baldwin, R. and P. Krugman (1989), "Persistent Trade Effects of Large Exchange Rate Shocks", The Quarterly Joumal of Economics vol.CIV, no. 4 (November) pp.635-654.

Caballero, R. (1991) "On the Sign of the Invesment-Uncertainty Relationship." American Economic Review vol.81 no.1 (March) pp.279-288.

Campa, J. and L. Goldberg (1994), "Invesment in Manufacturing, Exchange Rates and External Exposure", Joumal of International Economics (forthcoming),

Caves, R. (1989), "Exchange Rate Movements and Foreign Direct Investment in the United States" in The Internationalization of United States Markets, edited by Audretsch and Claudon (New York University Press).

Craine, R. (1989), "Risky Business: The Allocation of Capital," Joumal of Monetary Economics (March) vol.23 pp.210-218.

Cushman, D.O. (1985), "Real Exchange Rate Risk, Expectations, and the Level of Direct Investoment," Review of Economics and Statistics vol.67:2 (May).

Cushman, D.O. (1988), "Exchange Rate Uncertainty and Foreign Direct Investment in the United States" Weliwirschafiliches Archiv 124:2 pp.322-334.

De Meza, D. and F. van der Ploeg (1987), "Production Flexibility as a Motive for Multinationality," Journal of Industrial Economics vol.35 no.3 (March) pp.343-351.

Dixis, A. (1989) "Entry and Exit of Firms under Uncertainty", Joumal of Political Economy vol.97. no.3 pp.620-638.

Dombusch, R. (1989) "Credibility, debt and unemployment: Ireland's failed stabilization," Economic Policy vol.4 pp.174-201.

Dufey, G. and S.L. Srinivasulu (1984), "The Case for Corporate Management of Foreign Exchange Risk," Financial Management vol.12, no.4, pp.54-62.

Edison, H. and M. Melvin (1990), "The Determinants and Implications of the Choice of an Exchange Rate System," in eds. Harof and Willet, Monetary Policy for a Global Economy (American Enterprise Institute: Washington, D.C.).

Ethier, W. J. (1986) "The Multinational Firm", Quarterly Joumal of Economics 101:4 (November) pp.805-833. 
Froot, K., and J. Stein (1991), "Exchange Rates and Foreign Direct Investrnent: An Imperfect Capital Markets Approach", Quarterly Joumal of Economics (November) pp.1191-1217.

Goldberg. L. (1993), "Exchange Rates and Investment in United States Industry", Review of Economics and Statistics (November).

Goldberg, L. and C. Kolstad (1993), "Foreign Direct Investment, Exchange Rate Variability and Demand Uncertainty," University of Mlinois Bureau of Economic and Business Research, working paper \#93-0158.

Hartman. R. (1972), "The Effects of Price and Cost Uncertainty on Investment," Joumal of Economic Theory (October) vol.5 pp.258-266.

Jarrow, R. A. (1988), Finance Theory, (Prentice-Hall: Englewood Cliffs, New Jersey).

Klein, M. and E. Rosengren (1994), "The Real Exchange Rate and Foreign Direct Investment in the United States: Relative Wealth vs. Relative Wage Effects," Joumal of Intemasional Economics vol.36 (May) pp.373-389.

Lawrence, R. (1993) "Japan's Low Level of Inward Investment: The Role of Inhibitions on Acquisitions," in ed. K.Froot Contemporary Issues in Foreign Direct Investment, (NBER and University of Chicago Press).

Lipsey, R.E., (1993) "Foreign Direct Investment in the United States: Changes Over Three Decades", in ed. K.Froot Contemporary Issues in Foreign Direct Investment, (NBER and University of Chicago Press).

Mussa, M. (1982), "A Model of Exchange Rate Dynamics," Journal of Political Economy vol.90 no.1, pp.74-104.

Pindyck, R. (1988), "Irreversible Investment, Capacity Choice, and the Value of the Firm," American Economic Review (December) vol.78 pp.969-985.

Rodriguez, R. (1981). "Corporate Risk Management: Theme and Aberrations," Joumal of Finance (May) pp.427-439.

Slemrod, J. (1989), "Tax Effects on Foreign Direct Investment in the US: Evidence from a Cross Country Comparison," NBER working paper \#3042 (July).

Stock, J. (1992). "Unit Roots and Trend Breaks," manuscript (Harvard University).

Wolak, F.A. and C.D. Kolstad (1991), "Homogeneous Input Demand Under Price Uncertainty," American Economic Review vol.81: 514-38. 


\section{Technical Appendix}

Proof of Proposition 2: Totally differentiate the furst-order condicions (7) to obtain:

$\left[\begin{array}{ll}\frac{\partial^{2} E U}{\partial q^{2}} & \frac{\partial^{2} E U}{\partial q \partial \theta} \\ \frac{\partial^{2} E U}{\partial \theta \partial q} & \frac{\partial^{2} E U}{\partial \theta^{2}}\end{array}\right]\left[\begin{array}{l}\frac{d q}{d x} \\ \frac{d \theta}{d x}\end{array}\right]=\left[\begin{array}{l}-\frac{\partial^{2} E U}{\partial q \partial x} \\ -\frac{\partial^{2} E U}{\partial \theta \partial x}\end{array}\right]$

(A-1)

whire $E U=E[U(\pi)]$ and $\mathrm{x}$ can be $\rho, \sigma_{,}$, or $\sigma_{5}$. Cramer's rule is applied to determine $\partial \theta / \partial x$ and $\partial g / \partial x$. We know that the left-hand side matrix of (A-1) is negative semi-definite, and thus its determinant is positive, since $E U$ is striculy concave by assumption. Since at an optimum $A=B=0$ (from ey. $7 \mathrm{a}$ and $7 \mathrm{~b}$ ), and eliminating the minus sign of the right-hand-side vector, the following holds $\operatorname{sign} \frac{d \theta}{d x}=-\operatorname{sign}\left|\begin{array}{cc}\frac{\partial\left(A-P^{\prime} B\right)}{\partial q} & \frac{\partial\left(A-P^{\prime} B\right)}{\partial x} \\ \frac{\partial B}{\partial q} & \frac{\partial B}{\partial x}\end{array}\right|=-\operatorname{sign}\left(\frac{\partial A}{\partial q} \frac{\partial B}{\partial x}-\frac{\partial A}{\partial x} \frac{\partial B}{\partial q}\right)=-\operatorname{sign}(\Delta)$ and $\operatorname{sign} \frac{d q}{d x}=-\operatorname{sign}\left(\frac{\partial B}{\partial \theta} \frac{\partial A}{\partial x}-\frac{\partial A}{\partial \theta} \frac{\partial B}{\partial x}\right)$

Note that $\frac{\partial A}{\partial q}=2 P(q)+P^{\prime \prime}(q) q-\gamma \sigma_{a}^{2}\left[1+\sigma_{a}^{2}\left(1+\rho^{2}\right)\right]<0$

$$
\begin{aligned}
& \frac{\partial B}{\partial q}=\gamma q^{2} P(q) \sigma_{e}^{2}<0 \\
& \frac{\partial A}{\partial \theta}=2 \gamma q \sigma_{a}^{2}\left[P(q)-\theta+\rho \frac{\sigma_{\delta}}{\sigma_{A}}\right]=0 \\
& \frac{\partial B}{\partial \theta}=-\gamma q^{2} \sigma^{2}<0 \\
& \frac{\partial A}{\partial x}=\left\{\begin{array}{l}
\sigma_{c} \sigma_{b}+2 q \gamma \sigma_{b}^{2}\left(1-\sigma_{b}^{2}\right), \quad x=\rho \\
\rho \sigma_{b}-2 q \gamma \sigma_{b} \sigma_{b}^{2}\left(1+\rho^{2}\right) \leq 0, x=\sigma_{,} \\
\rho \sigma_{b}-2 q \gamma \sigma_{b}\left(1+\sigma_{c}^{2}\left(1+\rho^{2}\right)\right) \leq 0 \quad, x=\sigma_{b}
\end{array}\right. \\
& \frac{\partial B}{\partial x}= \begin{cases}\gamma q^{2} \sigma_{c} \sigma_{b}>0, & x=\rho \\
-\gamma q^{2} \rho \sigma_{b} \geq 0, & x=\sigma_{b} \\
\gamma q^{2} \rho \sigma_{c} \leq 0, & x=\sigma_{5}\end{cases}
\end{aligned}
$$

The sign of $(\mathrm{A}-4 \mathrm{a})$ is indeterminate; the sign of the other equations in $\mathrm{A}-4$ follow from Corollary 1 (i.e $\rho \leq 0)$, Lemma 1 , and the proposition assumptions. Only $d \theta / d x$ for $x=\sigma$, can be definitively signed.

Proof of Proposition 3: Using the above notation it is easy to demonstrate that $\frac{\partial \Delta}{\partial \rho} \geq 0$ and $\left.\Delta\right|_{\text {omo }}<0$. Since $\rho \leq 0$, this implies $\Delta<0$ which implies $\frac{d \theta^{\circ}}{d \rho}>0$. 


\section{Table A1: Data Sources}

\section{Foreign Direct Investment Series}

$q^{i}$ : Bilateral foreign direct investment flows between the United States and Canada, Japan, and the United Kingdom. Source: The Survey of Current Business.

\section{Country Investment Series}

$q_{i}$ : Aggregate investment by each country $i$ are non-seasonally adjusted data.

United States: Non-Residential Fixed Investment, source: the National Income and Product Accounts. ${ }^{2 b}$

Japan: Gross Fixed Capital Formation, source: Economic Planning Agency (of Japan).

United Kingdom: Gross Fixed Capital Formation, source: Central Statistical Office, data reported in Economic Trends 1992 Supplement

Canada: Gross Fixed Capital Formation.

\section{Bilateral Exchange Rates}

Each bilateral real exchange rate is defined as the product of the source country nominal bilateral exchange rate mulciplied by the destination country price index and divided by the source country price index. The nominal exchange-rate data are from the International Financial Statistics (IMF) and the price indices are CPI data drawn from the OECD.

\section{Real GDP}

Nominal GDP for each country i, deflated by the respective CPI series, with data drawn from the International Financial Statistics (IMF) and the $O E C D$, respectively.

a: The quarterly data are from "United States International Transections Tables", by the United States Department of Commerce. The series are "Private Foreign Direct Investment into the United States" and "United States Direct Invesment, Private Assets Abroad".

b: We have also conducted all of the regression analysis using a denominator of domestic investment net of total net foreign direct investment inflows, in order to adjust for the forejgn source invesument included in the total domestic investment measures. None of our results are significantly altered by this adjustment, so we report only the results using total invesment in the denominator. 


\begin{tabular}{|c|c|c|c|c|c|}
\hline \multirow[t]{3}{*}{ Table A2 } & \multicolumn{5}{|c|}{$\begin{array}{l}\text { Descriptive Statistics on Variance and Covariance Measures } \\
\text { (period averages) }\end{array}$} \\
\hline & \multicolumn{2}{|c|}{$\begin{array}{l}\text { Dormalized sid. } \\
\text { dev. of real } \\
\text { exchange rale }\end{array}$} & $\begin{array}{l}\text { correlation: real } \\
\text { exchange rate and } \\
\text { destination market } \\
\text { GDP shocks }\end{array}$ & $\begin{array}{c}\text { normalized std } \\
\text { dev. of real } \\
\text { destination market } \\
\text { GDP }\end{array}$ & \multirow[t]{2}{*}{$\begin{array}{l}\text { destination market } \\
\text { counory }\end{array}$} \\
\hline & $78-84$ & 85.91 & $78-84 \quad 85-91$ & $85-91$ & \\
\hline $\begin{array}{l}\text { yen/USS real } \\
\text { exchange rate }\end{array}$ & 0.094 & 0.111 & \begin{tabular}{cr|}
-0.397 & -0.396 \\
$(89.3 \%)$ & $(85.7 \%)$ \\
\end{tabular} & 0.037 & United Stries \\
\hline $\begin{array}{l}\text { pound/USS real } \\
\text { exchange rate }\end{array}$ & 0.098 & 0.093 & $\begin{array}{cr}0.107 & -0.311 \\
(42.9 \%) & (82.1 \%) \\
\end{array}$ & - & United States \\
\hline $\begin{array}{l}\text { CanSJUSS real } \\
\text { exchange rate }\end{array}$ & 0.029 & 0.035 & $\begin{array}{cr}0.109 & -0.123 \\
(46.4 \%) & (67.9 \%) \\
\end{array}$ & - & United States \\
\hline $\begin{array}{l}\text { USS/yen real } \\
\text { exchange rate }\end{array}$ & 0.097 & 0.109 & $\begin{array}{cr}0.025 & 0.144 \\
(53,6 \%) & (42.9 \%) \\
\end{array}$ & 0.079 & Japan \\
\hline $\begin{array}{l}\text { USS/pound real } \\
\text { exchange rate }\end{array}$ & $0 . \overline{098}$ & 0.089 & $\begin{array}{cc}0.145 & 0.237 \\
(28.6 \%) & (42.9 \%) \\
\end{array}$ & 0.042 & United Kingdom \\
\hline $\begin{array}{l}\text { USS/CanS real } \\
\text { exchange rale }\end{array}$ & 0.030 & 0.035 & $\begin{array}{cc}-0.335 & 0.199 \\
(96.4 \%) & (46.4 \%)\end{array}$ & 0.046 & Cansds \\
\hline
\end{tabular}




\begin{tabular}{|c|c|c|c|c|c|c|}
\hline \multirow[t]{2}{*}{$\begin{array}{l}\text { Table } \\
\text { A3 }\end{array}$} & \multicolumn{6}{|c|}{$\begin{array}{l}\text { p-values from Augmented Dickey Fuller tests for Unit Roots. } \\
\text { Tests performed using constant \& no trend (c), constant and tread (t), neither constant or } \\
\text { trend (n). and with range of lag lengths. UR = Unit Root }\end{array}$} \\
\hline & & description & $\begin{array}{l}\text { Uniled Stales } \\
\text { [\#obs.=\$2] }\end{array}$ & $\begin{array}{c}\text { Canada } \\
{[\# \text { obs.=52] }}\end{array}$ & $\begin{array}{c}\text { Japan } \\
\text { [Hobs.=52] }\end{array}$ & $\begin{array}{c}\text { U.K. } \\
\text { [\#obs.=52] }\end{array}$ \\
\hline $\begin{array}{l}\text { FDI share of } \\
\text { US into } \\
\text { destination }\end{array}$ & & & n.a. & $\begin{array}{c}\text { Ic: } p=5 \\
\text { Reject UR }\end{array}$ & $\begin{array}{l}\text { Ic: } p=1 \\
\text { Reject UR }\end{array}$ & $\begin{array}{c}\text { 4c:p=5 } \\
\text { Reject UR }\end{array}$ \\
\hline $\begin{array}{l}\text { FDI of sour } \\
\text { into US as } \\
\text { source share }\end{array}$ & & & n.a. & $\begin{array}{c}\text { Sc: } p=5 \\
\text { Reject UR }\end{array}$ & $\begin{array}{c}\text { 3t: } p>10 \\
\text { Comnot Reject }\end{array}$ & $\begin{array}{c}4 c: \text { p } 10 \\
\text { Cannot Reject }\end{array}$ \\
\hline$p(i . j)$ & & $\begin{array}{c}\text { USS } \\
\text { destination }\end{array}$ & D.a. & $\begin{array}{c}4 t: p>10 \\
\text { Cannot Reject }\end{array}$ & $\begin{array}{c}\text { 4n:p=S } \\
\text { Reject UR }\end{array}$ & $\begin{array}{c}4 n: p=1 \\
\text { Reject UR }\end{array}$ \\
\hline$p(i, j)$ & & $\begin{array}{l}\text { destination' } \\
\text { USS }\end{array}$ & n.a. & $\begin{array}{c}\text { 4n:p=1 } \\
\text { Reject UR }\end{array}$ & $\begin{array}{l}\text { 4a: p=10 } \\
\text { Reject UR }\end{array}$ & $\begin{array}{c}6 x \text { p>10 } \\
\text { Cannot Reject }\end{array}$ \\
\hline$\sigma_{e}(i, j)$ & & $\begin{array}{c}\text { US\$1 } \\
\text { destination }\end{array}$ & n.a. & $\begin{array}{c}\text { Ic: } p=1 \\
\text { Reject UR }\end{array}$ & $\begin{array}{c}\text { 1c:p=1 } \\
\text { Reject UR }\end{array}$ & $\begin{array}{c}\text { 3c: p>10 } \\
\text { Cannot Reject }\end{array}$ \\
\hline$\sigma_{e}(i j)$ & & $\begin{array}{c}\text { destination/ } \\
\text { USS }\end{array}$ & D.2. & $\begin{array}{c}\text { 1c: } p=1 \\
\text { Reject UR }\end{array}$ & $\begin{array}{c}\text { 1ep=1 } \\
\text { Reject UR }\end{array}$ & $\begin{array}{c}\text { 3c: p>10 } \\
\text { Cannot Reject }\end{array}$ \\
\hline $\begin{array}{l}\text { real GDP } \\
\text { volatiliny }\end{array}$ & & & $\begin{array}{c}4 c: p=5 \\
\text { Reject UR }\end{array}$ & $\begin{array}{c}4 t: p=5 \\
\text { Reject UR }\end{array}$ & $\begin{array}{c}4 c: p>10 \\
\text { Cannol Reject }\end{array}$ & $\begin{array}{c}\text { 5c: p>10 } \\
\text { Cannot Reject }\end{array}$ \\
\hline $\begin{array}{l}\text { real exchang } \\
\text { rale }\end{array}$ & & $\begin{array}{c}\text { US\$) } \\
\text { destination }\end{array}$ & n.a. & $\begin{array}{c}\text { 3c: p>10 } \\
\text { Cannot Reject }\end{array}$ & $\begin{array}{c}\text { 1c: p>10 } \\
\text { Cannot Reject }\end{array}$ & $\begin{array}{c}\text { 6c: p>10 } \\
\text { Cannot Reject }\end{array}$ \\
\hline $\begin{array}{l}\text { real exchang } \\
\text { rate }\end{array}$ & & $\begin{array}{l}\text { destination' } \\
\text { USS }\end{array}$ & n.a. & $\begin{array}{c}\text { 3c: } p>10 \\
\text { Cannot Reject }\end{array}$ & $\begin{array}{c}\text { 1c: p>10 } \\
\text { Cannot Reject }\end{array}$ & $\begin{array}{c}\text { 6c: p>10 } \\
\text { Cannot Reject }\end{array}$ \\
\hline real GDP & & & $\begin{array}{c}\text { 5t: } p>10 \\
\text { Cannot Reject }\end{array}$ & $\begin{array}{c}6 t: p>10 \\
\text { Cannot Reject }\end{array}$ & $\begin{array}{c}4 t: p>10 \\
\text { Cannot Reject }\end{array}$ & $\begin{array}{c}4 t: p>10 \\
\text { Cannot Reject }\end{array}$ \\
\hline
\end{tabular}

